\title{
Korelasi Positif Kegiatan Ekstrakurikuler dengan Tingkat Stres pada Anak Sekolah Dasar
}

Putu Anindia Sekarningrum, IGA Trisna Windiani, IGAN Sugitha Adnyana

Bagian Ilmu Kesehatan Anak Fakultas Kedokteran Universitas Udayana/RSUP Sanglah Denpasar

Latar belakang. Kompetisi antar orangtua merupakan salah satu penyebab munculnya sindrom hurried child, yaitu fenomena percepatan perkembangan anak. Anak diberi berbagai kegiatan ekstrakurikuler setiap minggu yang bertujuan untuk meningkatkan kemampuan anak. Hubungan orangtua dan anak yang tidak sehat cenderung membuat anak merasa tertekan ketika menjalankan kegiatan akademik mereka. Kesenjangan antara tuntutan dari orangtua dan kemampuan diri anak akan menimbulkan kondisi stres di bidang akademik pada anak.

Tujuan. Mencari besar korelasi antara kegiatan ekstrakurikuler dengan tingkat stres pada anak sekolah dasar.

Metode. Digunakan rancangan penelitianobservasional analitik dengan desain potong lintang. Penentuan lokasi dan subjek penelitian digunakan metode purposive sehingga terpilih Sekolah Dasar Swasta C Denpasar.

Hasil. Berdasarkan analisis korelasi dengan uji korelasi Pearson, didapatkan kegiatan ekstrakurikuler memiliki korelasi positif lemah dengan tingkat stres $(\mathrm{r}=0,309)$. Semakin lama mengikuti kegiatan ekstrakurikuler di bidang pelajaran sekolah dalam seminggu maka semakin tinggi skor stres $(\mathrm{r}=0,403)$ dan semakin lama mengikuti kegiatan ekstrakurikuler di bidang seni dalam seminggu maka semakin tinggi skor stres $(\mathrm{r}=0,166)$.

Kesimpulan. Kegiatan ekstrakurikuler memiliki korelasi positif dengan tingkat stres pada anak sekolah dasar. Sari Pediatri 2017;19(3):145-9

Kata kunci: kegiatan ekstrakurikuler, stres, anak

\section{Positive Correlation Extracurricular Activities with The Stress Levels in Primary School Children}

Putu Anindia Sekarningrum, IGA Trisna Windiani, IGAN Sugitha Adnyana

Background. Competition among parents is one of the reasons for the emergence of hurried child syndrome which is a child phenomenon characterized by an accelerated development. One of the characteristics is the child is given various extracurricular activities every week that aims to improve one's ability. A poor parent and child relationship tends to make children feel depressed while performing their academic activities. The discrepancy between the parents' demands and the children abilities will lead to stressful conditions in the academic field for the children.

Objective. To determine the actual correlations between extracurricular activities and the level of stress in primary school children. Methods. This study used an analytic observational research method with a cross sectional design. Determination of location and research subject was done by purposive sampling, hence the selection of Private Elementary School C in Denpasar.

Result. Based on the correlation analysis using Pearson correlation test, it was demonstrated that extracurricular activity had a weak positive correlation with the stress level $(r=0.309)$. The longer the extracurricular activities in the field of school subjects within a week, the higher the stress score will be $(r=0.403)$ and the longer the extracurricular activities in the field of art within a week, the higher the stress score will be $(\mathrm{r}=0.166)$.

Conclusion. Extracurricular activities had a positive correlation with the stress levels in primary school children. Sari Pediatri 2017;19(3):145-9

Keywords: extracurricular activities, stress, children

Alamat korespondensi: dr. Putu Anindia Sekarningrum. Bagian/SMF Ilmu Kesehatan Anak FK UNUD/RSUP Sanglah Denpasar, Jl. Pulau Nias Denpasar-Bali. Email: anindia.md@gmail.com 
Putu Anindia Sekarningrum dkk: Korelasi positif kegiatan ekstrakurikuler dengan tingkat stres pada anak sekolah dasar

B angsa Indonesia memerlukan sumber daya manusia yang siap pakai dan mampu bersaing. Tantangan global dalam persaingan antar bangsa serta agenda pembangunan menuntut sumber daya manusia berkualitas tinggi yang mampu bersaing dalam skala nasional dan, internasional. Berbagai macam model pendidikan ditawarkan untuk memenuhi tuntutan globalisasi tersebut. Orangtua cenderung memberikan tambahan jadwal kegiatan ekstrakurikuler untuk meningkatkan kemampuan anaknya. Fenomena tersebut merupakan salah satu "penyakit" yang dalam dua dekade terakhir menjadi epidemi di masyarakat, dan dikenal dengan istilah hurried child. ${ }^{1}$

Sekitar dua puluh tahun yang lalu, seorang ahli psikologi Amerika, David Elkind, memperkenalkan sebuah istilah baru yakni hurried child untuk menggambarkan fenomena anak yang dipercepat perkembangannya. Salah satu cirinya adalah anak diberi berbagai kegiatan ekstrakurikuler setiap minggu yang bertujuan untuk meningkatkan kemampuan di bidang akademik, sosial, olahraga, dan budaya. Berbagai aktivitas tersebut dilakukan di bawah pengawasan orangtua sehingga tidak untuk bersenangsenang, tetapi lebih diarahkan untuk mencapai suatu tujuan. ${ }^{1}$

Orangtua berpendapat bahwa mereka dikatakan orangtua yang baik jika anak mereka mampu mencapai prestasi tertentu. Jadwal yang terlalu padat tidak selamanya berakibat baik, justru dapat menimbulkan tekanan. Tekanan tersebut dapat menyebabkan harga diri yang rendah, stres, dan bunuh diri. Salah satu fenomena yang menarik adalah semakin mudanya usia penderita stres. ${ }^{1,2}$ Suatu studi terhadap anak sekolah dasar kelas 4 sampai 6 di Bogor pada tahun 2013 didapatkan 47,7\% mengalami stres akademik. ${ }^{2}$ National association of school psychologists mendefinisikan stres sebagai suatu respon terhadap situasi atau faktor yang menimbulkan emosi negatif atau perubahan fisis atau kombinasi dari perubahan fisis dan emosi. ${ }^{3}$ Anak hanya memiliki sedikit pengalaman untuk belajar sehingga situasi yang menyebabkan perubahan kecil dapat menimbulkan stres terhadap anak. ${ }^{4}$

Di Amerika Serikat, suatu studi terhadap 227 anak usia 4-6 tahun yang dididik secara diktator untuk mencapai nilai akademik yang tinggi, didapatkan memiliki kemampuan dan harapan yang lebih rendah untuk sukses pada tugas akademik mereka serta ketergantungan secara signifikan terhadap orang dewasa. ${ }^{5}$ Studi terhadap 60 anak sekolah dasar di Bogor pada tahun 2009, menemukan terdapat korelasi antara anak sibuk dengan tingkat stres $(r=0,298){ }^{6}$ Fenomena tersebut menegaskan mengenai pentingnya mempelajari tingkat stres pada anak sekolah dasar. Tujuan utama penelitian ini adalah mencari besar korelasi antara jenis dan jam kegiatan ekstrakurikuler yang meliputi bidang pelajaran sekolah, seni, dan olahraga dalam seminggu dengan tingkat stres pada anak sekolah dasar.

\section{Metode}

Digunakan rancangan penelitian observasional analitik dengan desain potong lintang. Penentuan lokasi penelitian digunakan metode purposive, dengan pertimbangan bahwa sekolah merupakan sekolah dasar (SD) swasta favorit yang memiliki jadwal padat serta jumlah anak dengan kegiatan ekstrakurikuler yang cukup tinggi sehingga terpilih SD Swasta C Denpasar.

Pengambilan data dilaksanakan pada bulan Juli 2016 secara bersamaan pada seluruh sampel. Populasi target adalah anak SD dan populasi terjangkau adalah anak SD yang bersekolah di SD Swasta C Denpasar pada bulan Juli 2016. Sampel dalam penelitian ini adalah purposive sample, yaitu anak kelas 5 SD. Anak kelas 5 memiliki waktu yang lebih banyak untuk melakukan kegiatan ekstrakurikuler (les pelajaran/ kursus kesenian/klub olahraga) dan memiliki jadwal pelajaran yang cukup padat karena akan dipersiapkan untuk mengikuti ujian nasional. Kriteria inklusi dari penelitian ini adalah anak terdaftar sebagai kelas 5 SD Swasta C Denpasar, hadir saat penelitian dilaksanakan, dan bersedia untuk berpartisipasi dalam penelitian ini. Kriteria eksklusi adalah anak yang mendapat terapi psikologi, cacat fisik, dan sakit saat penelitian dilaksanakan.

Tingkat stres adalah status emosi subjek yang diukur dengan instrumen psychometric properties of the depression anxiety stres scale (DASS) 42 dan dibagi menjadi 5, yaitu normal, ringan, sedang, berat, dan sangat berat. ${ }^{7}$ Psychometric properties of the depression anxiety stres scale 42 menunjukkan validitas diskriminan dengan konsistensi internal yang tinggi dan nilai reliabilitas 0,91 yang diuji berdasarkan Cronbac's alpha. ${ }^{7}$ Jenis kegiatan ekstrakurikuler adalah jumlah kegiatan di luar jam pelajaran pokok 
Tabel 1. Karakteristik subjek penelitian

\begin{tabular}{|c|c|c|}
\hline Karakteristik & $\mathrm{n}(170)$ & $(\%)$ \\
\hline \multicolumn{3}{|l|}{ Jenis kelamin } \\
\hline Lelaki & 85 & 50,0 \\
\hline Perempuan & 85 & 50,0 \\
\hline \multicolumn{3}{|l|}{ Umur (tahun) } \\
\hline 9 & 8 & 4,7 \\
\hline 10 & 152 & 89,4 \\
\hline 11 & 10 & 5,9 \\
\hline \multicolumn{3}{|c|}{$\begin{array}{l}\text { Lamanya belajar di rumah dalam sehari } \\
\text { (jam) }\end{array}$} \\
\hline$\leq 2$ & 117 & 68,8 \\
\hline$>2$ & 53 & 31,2 \\
\hline \multicolumn{3}{|c|}{$\begin{array}{l}\text { Jenis kegiatan ekstrakurikuler yang } \\
\text { diikuti (jumlah kegiatan/minggu) }\end{array}$} \\
\hline 1 & 28 & 16,5 \\
\hline 2 & 47 & 27,6 \\
\hline 3 & 44 & 25,9 \\
\hline 4 & 26 & 15,3 \\
\hline 5 & 12 & 7,1 \\
\hline 6 & 8 & 4,7 \\
\hline 7 & 3 & 1,8 \\
\hline 8 & 1 & 0,6 \\
\hline 9 & 1 & 0,6 \\
\hline \multicolumn{3}{|c|}{$\begin{array}{l}\text { Lamanya kegiatan ekstrakurikuler } \\
\text { pelajaran sekolah (jam/minggu) }\end{array}$} \\
\hline Tidak mengikuti & 3 & 1,8 \\
\hline$<6$ & 22 & 12,9 \\
\hline $6-12$ & 91 & 53,5 \\
\hline$\geq 12$ & 54 & 31,8 \\
\hline \multicolumn{3}{|c|}{$\begin{array}{l}\text { Lamanya kegiatan ekstrakurikuler seni } \\
\text { (jam/minggu) }\end{array}$} \\
\hline Tidak mengikuti & 93 & 54,7 \\
\hline$<6$ & 71 & 41,8 \\
\hline 6-12 & 6 & 3,5 \\
\hline \multicolumn{3}{|c|}{$\begin{array}{l}\text { Lamanya kegiatan ekstrakurikuler } \\
\text { olahraga(jam/minggu) }\end{array}$} \\
\hline Tidak mengikuti & 69 & 40,6 \\
\hline$<6$ & 93 & 54,7 \\
\hline $6-12$ & 6 & 3,5 \\
\hline$\geq 12$ & 2 & 1,2 \\
\hline
\end{tabular}

yang dilaksanakan di luar sekolah untuk menunjang program pendidikan yang diikuti oleh subjek dalam seminggu. ${ }^{7-9}$ Kegiatan ekstrakurikuler dibagi menjadi 3 bidang, yaitu bidang kognitif/pelajaran sekolah (les/ kursus matematika, Bahasa Inggris, dan lainnya), seni (menari, melukis, menabuh, alat musik dan lainnya), dan olahraga (sepak bola, renang, basket, karate, dan lainnya). ${ }^{5,10}$ Jam kegiatan ekstrakurikuler adalah lamanya subjek mengikuti kegiatan ekstrakurikuler dalam seminggu, dibedakan menjadi tidak mengikuti, $<6,6-12$, dan $\geq 12$ jam. ${ }^{11,12}$ Studi oleh Fredricks dkk ${ }^{12}$ menemukan bahwa nilai dan kondisi siswa yang mengikuti lebih dari 12 jam kegiatan ekstrakurikuler menurun. ${ }^{12}$

Penelitian ini dilaksanakan pada waktu bersamaan dengan pengisian kuesioner oleh subjek sendiri. Semua data dikumpulkan kemudian dianalisis dengan uji korelasi Pearson menggunakan program SPSS (statistical product and service solutions) 17. Penelitian ini sudah mendapat ijin dari komite etik Penelitian Fakultas Kedokteran Universitas Udayana/Rumah Sakit Umum Pusat Sanglah Denpasar dengan nomor protokol 257.02.1.2016.

\section{Hasil}

Jumlah subjek adalah 170 , rerata usia 10,01 tahun dengan standar deviasi 0,3 dan rentang usia 9-11 tahun. Karakteristik subjek penelitian tertera pada Tabel 1.

Berdasarkan kuesioner DASS 42 didapatkan tingkat stres bervariasi, tetapi $62,9 \%$ subjek masih dalam batas normal. Berdasarkan analisis korelasi dengan uji korelasi Pearson pada Tabel 2, didapatkan jenis kegiatan ekstrakurikuler memiliki korelasi positif lemah dengan tingkat stres $(r=0,309)$. Semakin lama mengikuti kegiatan ekstrakurikuler di bidang pelajaran sekolah dalam seminggu maka semakin tinggi skor stres $(r=0,403)$ dan semakin lama mengikuti kegiatan ekstrakurikuler di bidang seni dalam seminggu maka semakin tinggi skor stres $(\mathrm{r}=0,166)$.

Tabel 2. Hasil analisis korelasi Pearson

\begin{tabular}{lcc}
\hline Variabel & $\begin{array}{c}\text { Koefisien } \\
\text { korelasi (r) }\end{array}$ & $\mathrm{p}$ \\
\hline $\begin{array}{l}\text { Jenis kegiatan } \\
\text { ekstrakurikuler }\end{array}$ & 0,309 & $0,001^{*}$ \\
$\begin{array}{l}\text { Jam kegiatan ekstrakurikuler } \\
\text { pelajaran sekolah per } \\
\text { minggu }\end{array}$ & 0,403 & $0,001^{*}$ \\
$\begin{array}{l}\text { Jam kegiatan ekstrakurikuler } \\
\text { seni per minggu }\end{array}$ & 0,166 & $0,031^{*}$ \\
$\begin{array}{l}\text { Jam kegiatan ekstrakurikuler } \\
\text { olahraga per minggu }\end{array}$ & 0,033 & 0,671 \\
$\begin{array}{l}\text { Keterangan: }{ }^{*} \text { bermakna } \mathrm{p}<0,05, \mathrm{p}=\text { probabilitas } \\
\text { Kerang }\end{array}$ &
\end{tabular}




\section{Pembahasan}

Stres merupakan reaksi tubuh terhadap situasi yang menimbulkan tekanan, perubahan, dan ketegangan emosi. Stres terjadi apabila anak merasa tidak mampu untuk menahan tekanan yang berasal dari luar dirinya (external pressure), misalnya tekanan dari temanteman, keluarga, dan sekolah atau dari dalam dirinya sendiri (internal pressure). ${ }^{8}$ Kegiatan ekstrakurikuler adalah kegiatan yang dilakukan oleh siswa di luar jam pelajaran pokok. Kegiatan ini terdapat pada setiap jenjang pendidikan dari sekolah dasar sampai universitas. Kegiatan ekstrakurikuler ditujukan agar siswa dapat mengembangkan kepribadian, bakat, dan kemampuannya., ${ }^{910}$

Jenis kegiatan ekstrakurikuler memiliki korelasi positif lemah dengan skor stres. Hasil ini sesuai dengan studi oleh Pranadji $\mathrm{dkk}^{6}$ yang melaporkan bahwa jumlah aktivitas di luar sekolah dalam satu minggu dan alokasi waktu aktivitas di luar sekolah memiliki pengaruh terhadap tingkat stres anak sekolah dasar di Bogor. Penelitian ini menggunakan rancangan penelitian observasional analitik dengan desain potong lintang dan pengukuran tingkat stres menggunakan kuesioner gejala stres. Suatu studi oleh Sudiana ${ }^{11}$ terhadap siswa menengah kejuruan usia 16-17 tahun di Bandung menemukan bahwa kegiatan ekstrakurikuler yang padat sebagai faktor penyebab stres akademik. Instrumen penelitian ini menggunakan kuesioner DASS 42 yang telah dilakukan uji validitas dan reliabilitas dengan nilai 0,97 .

Lama kegiatan ekstrakurikuler pelajaran sekolah memiliki korelasi sedang dengan tingkat stres, kegiatan ekstrakurikuler seni memiliki korelasi sangat lemah dengan tingkat stres, dan kegiatan ekstrakurikuler olahraga tidak memiliki korelasi yang bermakna dengan tingkat stres. Hasil penelitian ini sesuai dengan studi oleh Fredricks $\mathrm{dkk}^{12}$ yang melaporkan bahwa terdapat pengaruh positif dari satu sampai 12 jam kegiatan ekstrakurikuler dalam seminggu terhadap ujian anakanak. Siswa yang mengikuti lebih dari 12 jam kegiatan ekstrakurikuler, nilai dan kondisi mereka didapatkan menurun. Studi yang dilakukan oleh Metsapelto $\mathrm{dkk}^{13}$ terhadap anak usia 9-10 tahun di Jerman melaporkan bahwa kegiatan olahraga merupakan kegiatan ekstrakurikuler yang paling digemari. Kegiatan ekstrakurikuler seni dan olahraga dikaitkan dengan pencapaian prestasi akademik yang tinggi. Studi oleh Fredricks ${ }^{14}$ terhadap remaja di Amerika Serikat menemukan bahwa remaja yang mengikuti lebih dari 4 kegiatan ekstrakurikuler dan durasi waktu lebih dari 13 jam dalam seminggu menurunkan prestasi akademik. ${ }^{14} \mathrm{Hal}$ tersebut menunjukkan anak lebih banyak melakukan kegiatan pelajaran dan fungsi otak kiri lebih dominan sehingga diperlukan kegiatan seni dan olahraga yang disesuaikan dengan minat dan kemampuan anak. Otak kiri berperan dalam bidang matematika, tata bahasa, pemecahan masalah, memori, logika, analisis serta keteraturan. Otak kanan memiliki peran dalam bidang musik, seni, ruang, bentuk, warna, konsep, intuisi, perasaan serta kreativitas. Jika seseorang hanya mengaktifkan salah satu belahan otaknya dalam melakukan aktivitas, akan terjadi ketidakseimbangan fungsi kerja otak sehingga mempermudah mengalami gangguan mental. ${ }^{15}$ Suatu studi terhadap anak sekolah dasar di Amerika melaporkan bahwa program seni yang intensif, seperti musik, menari, dan seni visual dapat menurunkan kadar kortisol sehingga tingkat stres dapat berkurang. ${ }^{16}$ Keterbatasan dalam penelitian ini adalah tidak adanya karakteristik orangtua, lingkungan sosial, dan ekonomi subjek sehingga tidak didapatkan variasi dalam anggota subjek.

\section{Kesimpulan dan Saran}

Kegiatan ekstrakurikuler memiliki korelasi positif dengan tingkat stres pada anak sekolah dasar. Banyaknya ekstrakurikuler dalam seminggu memiliki korelasi positif lemah dengan tingkat stres. Lamanya kegiatan ekstrakurikuler pelajaran sekolah memiliki korelasi positif sedang dengan tingkat stres, kegiatan ekstrakurikuler seni memiliki korelasi positif sangat lemah dengan tingkat stres dan kegiatan ekstrakurikuler olahraga tidak memiliki korelasi yang bermakna secara statistik dengan tingkat stres. Kegiatan ekstrakurikuler anak sebaiknya beragam jenisnya dan tidak dilakukan lebih dari satu jam sehari. Orangtua tidak diperkenankan memaksa anak untuk mengikuti kegiatan ekstrakurikuler.

\section{Ucapan Terima Kasih}

Peneliti menyampaikan terima kasih atas bantuan dan kerjasama yang baik kepada kepala sekolah, guru Sekolah Dasar Swasta C Denpasar, dan orangtua subjek yang telah bersedia mengikuti penelitian. 


\section{Daftar pustaka}

1. Elkind D. The hurried child growing up too fast too soon. Diunduh pada 14 Oktober 2015. Didapat dari: http://powell. rivendellschool.net.

2. Oktamiati H, Putri YSE. Tingkat stres akademik anak usia sekolah terhadap sistem full day school di sekolah dasar Kabupaten Bogor. Diunduh pada 14 Oktober 2015. Didapat dari: http://lib.ui.ac.id.

3. National Association of School Psychologists. Stress in children and adolescents: tips for parent. Diunduh pada 14 Oktober 2015. Didapat dari: http://nasponline.org.

4. Haggerty RJ, Sherrod LR, Garmezy N, Rutter M. Stress, risk and resilience in children and adolescents; processes, mechanisms, and interventions. J Child Psychol Psychial 1996;37:237-9.

5. Stipek D, Feiler R, Daniels D, Milbum S. Effects of different instructional approaches on young children's achievement and motivation. Child Dev 1995;66:209-23.

6. Pranadji DK, Nurlaela. Faktor-faktor yang mempengaruhi tingkat stres pada anak usia sekolah dasar yang sibuk dan tidak sibuk. Jur Ilm Kel dan Kons 2009;2:57-63.

7. Antony M, Bieling P, Cox B, Enns M, Swinson R. Psychometric properties of the 42-item and 21-item versions of the Depression Anxiety Stress Scales in clinical groups and a community sample. Psychol Assess 1998;10:176-81.

8. Ben-Zur H, Zeidner M. Appraisals, coping and affective and behavioral reactions to academic stressors. Psychology 2012;3:713-21.

9. Anam S. Kegiatan ekstrakurikuler, pengertian, tujuan, dan fungsinya. Diunduh pada 20 Agustus 2016. Didapat dari: http:/lanam.kegiatan.ekstrakurikuler.html.

10. Brown SL, Nobiling BD, Teufel J, Birch DA. Are kids too busy?: early adolescents' perceptions of discretionary activities, overscheduling, and stress. J Sch Health 2011;81:574-80.

11. Sudiana D. Kondisi stres siswa sekolah menengah kejuruan dan faktor-faktor penyebabnya. Diunduh pada 20 Agustus 2016. Didapat dari: http://repository.upi.edu/skripsiview.

12. Fredricks JA, Eccles JS. Breadth of extracurricular participation and adolescent adjustment among African-American and European-American youth. J Res Adolesc 2010;20:307-33.

13. Metsapelto RL, Pulkkinen L. Socioemotional Behavior and School Achievement in Relation to Extracurricular Activity Participation in Middle Childhood. Scan J Educ Res 2012;56:167-82.

14. Fredricks JA. Extracurricular participation and academic outcomes: testing the over-scheduling hypothesis. J Youth Adolesc 2012;41:295-306.

15. Corballis MC. Left brain, right brain: facts and fantasies. PLoS Biol 2014;12:1-6.

16. Brown ED. Tapping the arts to teach r's: arts-integrated early childhood. Dalam: Lynn EC, Sandra W, penyunting. Advances in early education and day care. United Kingdom: Emerald Group Publishing; 2013.h.135-51. 